\title{
LOW MITOCHONDRIAL DNA SEQUENCE VARIATION IN THE MICROENDEMIC CUATRO CIÉNEGAS PLATYFISH XIPHOPHORUS GORDONI
}

\author{
Evan W. Carson ${ }^{1}$, Hector Espinosa-Pérez ${ }^{2}$, and Valeria Souza ${ }^{3}$
}

\begin{abstract}
The desert spring ecosystem of the Cuatro Ciénegas basin, Mexico, hosts an extraordinary but increasingly imperiled assemblage of native and endemic aquatic organisms. Among the more vulnerable to extinction is the microendemic Cuatro Ciénegas platyfish Xiphophorus gordoni, which is at particular risk due to its highly restricted distribution and small population size. Given the growing demands on water resources in this arid region, we conducted a survey of mitochondrial DNA sequence variation in the cytochrome $b$ gene to establish a baseline for long-term genetic monitoring of this endangered species. Fifty-eight specimens were collected from the 2 subpopulations known to persist, Laguna Santa Tecla (27) and Teclitas (31). Three haplotypes were observed across all samples, with 3 and 2 haplotypes observed at Laguna Santa Tecla and Teclitas, respectively. Sequence divergence ranged from $0.02 \%$ to $0.03 \%$ among variants and averaged 0.317 differences between populations. Haplotype and nucleotide diversities were moderately low in Laguna Santa Tecla (0.467 and 0.0008, respectively) and severely low in Teclitas $(0.065$ and 0.0001 , respectively). Exact tests revealed significant heterogeneity in haplotype distributions between sites $(P=0.006)$, as did the pairwise estimate of $\Phi_{S T}(0.135 ; P=0.005)$. Tests of deviation from neutrality were nonsignificant. Microendemism of $X$. gordoni and marginal substitution differences between the few extant haplotypes suggest that low genetic variation is a historical characteristic of this species; however, population declines associated with recent habitat loss have likely further compromised standing levels of genetic variation. Development of a long-term population and genetic monitoring program that incorporates multilocus nuclear DNA markers is advised and should be tied to a more thorough characterization of the basic biology and life history of this species, establishment of captive or refuge populations, and further improvement of habitat.
\end{abstract}

Resumen.-El ecosistema desértico de Cuatro Ciénegas es un oasis extraordinariamente diverso y amenazado por las presiones agrícolas a su acuífero profundo. Entre los organismos mas amenazados es el pez microendémico Xiphophorus gordoni, debido a su distribución restringida y a sus pequeños tamaños poblacionales. Dado que las demandas del agua por la agricultura en este desierto han incrementado, decidimos estudiar la estructura genética de estas poblaciones para establecer una base para monitorear a largo plazo a esta especie amenazada. La variación genética de la población de $X$. gordoni en Cuatrociénegas Coahuila fue evaluada utilizando métodos de genética de poblaciones utilizando como marcador el citocromo $b$ en 58 ejemplares de dos poblaciones microendémicas de estos peces que sobreviven en la Laguna Santa Tecla (27) y en Teclitas (31). Se observaron 3 haplotipos en el total de las muestras con 2 haplotipos presentes en cada sitio. La divergencia en las secuencias fue $0.02 \%-0.03 \%$ entre variantes con un promedio de 0.317 diferencias entre poblaciones. Esta diversidad de haplotipos y secuencias fue moderadamente baja en laguna de Santa Tecla $(0.467$ and 0.0008 , respectivamente) y muy baja en Teclitas $(0.065$ and 0.0001 , respectivamente). Se observó una heterogeneidad significativa entre sitios utilizando las pruebas exactas $(P=0.006)$ con un estimado $\Phi_{S T}(0.135 ; P=0.005)$. Las pruebas de desviación a la neutralidad fueron no significativas. El microendemismo de X. gordoni y las diferencias marginales en las tasas de sustitución en los haplotipos estudiados sugiere que la baja diversidad genética observada es parte histórica de la especie; sin embargo, la caída en la población debido a la pérdida del hábitat probablemente comprometerá aún más la diversidad genética de esta especie. Sugerimos el desarrollo de programas a largo plazo de monitoreo genético de esta especie en peligro de extinción, utlizando multiples marcadores nucleares, mismo que deberan unirse a estudis cuidadosos de la historia natural e historias de vida de esta especie. Tambien sugerimos el establecimiento de poblaciones cautivas o en refugios estables para mantener a la especie hasta que las polícicas sobre la conservación del ecosistema mejoren las posibilidades de esta especie.

The Cuatro Ciénegas basin, Mexico, hosts an expansive desert spring ecosystem that contains an extraordinary assemblage of native and endemic aquatic organisms (Minckley 1969). Endemism in this Chihuahuan Desert valley is comparable to that of the Galápagos Islands (Souza et al. 2012) and includes numerous fishes (Minckley 1969) and hydrobiid snails (Hershler 1984), as well as spectacularly diverse microbial fauna (Souza et al. 2006).

\footnotetext{
${ }^{1}$ Department of Biology, MSC03 2020, 1 University of New Mexico Way, Albuquerque, NM 87131-0001. E-mail: evan.carson@gmail.com

${ }^{2}$ Colección Nacional de Peces, Instituto de Biología, Universidad Nacional Autónoma de México, Ciudad Universitaria, 3er Cto. Exterior s/n México 04510 D.F.

${ }^{3}$ Departamento de Ecología Evolutiva, Instituto de Ecologia, UNAM AP. 25-275, Coyoacán 04510, México D.F., México
} 
Further, Cuatro Ciénegas is a rare, contemporary analogue of Precambrian communities, as stromatolites are a fundamental component of a metazoan-rich ecosystem (Winsborough 1990, Elser et al. 2005a, 2005b). Nonetheless, this exceptional and well-recognized biodiversity is critically imperiled due to longstanding and increasing demands for the limited water resources in this arid region.

Among the more vulnerable endemic organisms is the Cuatro Ciénegas platyfish Xiphophorus gordoni (Miller and Minckley 1963; IUCN Red List: http://www.iucnredlist.org/de tails/23157/0), which has the most geographically restricted distribution among the fishes in the basin (Miller and Minckley 1963). This northernmost representative of the genus was limited historically to the small and isolated Santa Tecla spring complex, but further range constriction occurred following habitat loss associated with initial opening $(\sim 1890-1910)$ and later lining $(\sim 1964)$ of the system-draining Canal de la Polilla (Minckley 1969, Minckley personal communication). Subsequent anthropogenic changes further degraded the system, though recent restoration efforts have ameliorated habitat quality. While introduced species possibly restricted $X$. gordoni to a habitat breadth narrower than its historical norm (Minckley, http://www.desertfishes.org/cuatroc/ organisms/tmm-fish-pages/xiphophorus-gor doni-abstract.php), this platyfish is generally considered a headspring endemic, as it has been observed only in vegetated inflows associated with the adjacent Lagunas Santa Tecla (type locality), Fresnos, and Quintero, and a few small pools (Kallman 1964, Minckley 1969), as well as Teclitas Spring and vegetated portions of the uppermost Canal de la Polilla (Carson personal observation). More recently, moderate search efforts in 2010 and 2011 (Carson personal observation) found $X$. gordoni in only Laguna Santa Tecla, Teclitas Spring, and vegetated, uppermost portions of Canal de la Polilla; the last is an artificial habitat downstream of the type locality.

Swordtails and platyfishes (genus Xiphophorus) have been studied extensively as model organisms, particularly in cancer research (Schartl 1995, Patton et al. 2010) and a variety of areas in evolutionary biology, such as speciation (Orr et al. 2004, Volff 2005), behavior (Cummings and Mollaghan 2006), hybridization (Culumber et al. 2012), and biodiversity
(Jones et al. 2012). Xiphophorus gordoni, however, is poorly known. Though this platyfish was discovered in 1961 (Miller and Minckley 1963), there has been a dearth of research on the species since. Knowledge of its basic biology and ecology remains scant and largely limited to findings from studies of histocompatibility (Kallman 1964, Lysne 1967) and a sparse account of reproduction and abiotic habitat conditions (Minckley, http://www.desertfishes .org/cuatroc/organisms/tmm-fish-pages/ xiphophorus-gordoni-abstract.php). Though the phylogeographic relationships of X. gordoni are better resolved (Meyer et al. 1994, 2006), the taxonomic status of this species has been subject to varied interpretation, including consideration as a subspecies of $X$. couchianus (Rosen and Bailey 1963, Kallman 1964, Rosen and Kallman 1969) and recognition as a microendemic taxon (its current status; Minckley 1969, 1984, Rosen 1979). As threats to the persistence of $X$. gordoni grow with increasing regional demands on water resources, conservation of this microendemic species will depend in part on a much better understanding of its biology, ecology, and population genetic characteristics.

This study provides the first direct assessment of genetic diversity in X. gordoni. Mitochondrial DNA sequence variation at the cytochrome $b$ (cyt $b$ ) gene was used to assess haplotypic variation and population structure of known remaining subpopulations. Baseline information on mtDNA sequence variation will aid establishment of a broader, long-term population genetic monitoring program for this increasingly at-risk species.

\section{Methods}

A total of $58 X$. gordoni specimens were collected from Laguna Santa Tecla (27) and the Teclitas headspring (31) in August 2011 (UNAM voucher numbers CNPE-IBUNAM 17843 and CNPE-IBUNAM17844, respectively) and October 2011 (UNAM voucher numbers CNPE-IBUNAM17845 and CNPE-IBUNAM 17846 , respectively). We preserved these specimens in $95 \%$ ethanol and extracted whole genomic DNA from muscle tissue by following the protocol of Tibbets and Dowling (1996). We assessed mitochondrial DNA sequence variation at a $601 \mathrm{bp}$ fragment of the cytb gene, using the primers LA and HD (Schmidt 
et al. 1998). Polymerase chain reaction amplifications were performed in $30-\mu \mathrm{L}$ reaction volumes of $\sim 100 \mathrm{ng}$ whole genomic DNA, 1X GoTaq Flexi Buffer (Promega, Madison, WI), $1.5 \mathrm{mM} \mathrm{MgCl} 2,0.5 \mu \mathrm{M}$ of each primer, 250 $\mu \mathrm{M}$ of each dNTP, and 1.7U GoTaq Taq polymerase (Promega). Amplifications used an initial $95{ }^{\circ} \mathrm{C}$ denaturation step, followed by 30 cycles at $95{ }^{\circ} \mathrm{C}$ for $1 \mathrm{~min}, 48^{\circ} \mathrm{C}$ for $1 \mathrm{~min}$, and $72{ }^{\circ} \mathrm{C}$ for $2 \mathrm{~min}$, with a 10 -min final extension at $72{ }^{\circ} \mathrm{C}$. A Big Dye Terminator Kit (version 3.1; Applied Biosystems, Foster City, CA) was used for sequencing reactions, per the manufacturer's recommendations. Products were separated on an ABI 3100 capillary sequencer, with visual alignment and editing of sequences performed in SEQUencher 4.0 (Gene Codes Corp., Ann Arbor, MI).

Genetic diversity was measured as number of haplotypes, haplotype diversity, and nucleotide diversity, as implemented in ARLEQUIN (Excoffier and Lischer 2010; version 3.5.1.2, http://cmpg.unibe.ch/software/arlequin35/). Pairwise genetic distances between haplotypes (p-distance model) and average number of differences between populations were calculated in Mega5 (Tamura et al. 2011). Homogeneity of cytb haplotype distributions between localities was tested and pairwise estimates of the $F_{S T}$ analogue $\Phi_{S T}$ were generated in ARLEQUIN, with significance determined through exact tests (Raymond and Rousset 1995, Goudet et al. 1996). Selective neutrality of cytb variation at each site was tested using Fu's (1997) $F_{S}$ statistic and $\mathrm{Fu}$ and Li's (1993) $D^{*}$ and $F^{*}$ statistics, as implemented in DNASP 5.10.01 (Rozas et al. 2003; http://www.ub.edu/dnasp/ [accessed October 2012]).

\section{RESUlTS}

Three haplotypes (A-C; GenBank Accession Numbers JX856169-JX856171) were observed in X. gordoni, including at Santa Tecla19 haplotype A (70.4\%), 6 haplotype B $(22.2 \%)$, and 2 haplotype $\mathrm{C}(7.4 \%)$ - and at Teclitas-30 haplotype A (96.8\%) and 1 haplotype C (3.2\%). Pairwise distances of haplotypes ranged from $0.2 \%$ to $0.3 \%$, and the average number of differences between populations was 0.317 . Haplotype diversity was over 7-fold higher at Laguna Santa Tecla (0.467) than at Teclitas (0.065), with a between-population average of 0.298 . A similarly large disparity was observed between Santa Tecla and Teclitas for nucleotide diversity $(0.00083 \pm 0.00081$ and 0.00011 \pm 0.00026 , respectively). Exact tests revealed significant heterogeneity of haplotype distributions between sites $(P=0.006)$, as did the pairwise estimate of $\Phi_{S T}=0.135(P=0.005)$. Tests of selective neutrality were nonsignificant for both sites, with $F_{S}=0.065(P=$ $0.287), F^{*}=0.681(P>0.10)$, and $D^{*}=0.820$ $(P>0.10)$ for Laguna Santa Tecla and $F_{S}=$ $-1.239(P=0.200), F^{*}=-1.774(P>0.10)$, and $D^{*}=-1.693(P>0.10)$ for Teclitas.

\section{Discussion}

Analyses of mtDNA sequence variation at cyt $b$ in the 2 populations of $X$. gordoni known to persist, Laguna Santa Tecla and Teclitas, revealed 3 variants, 2 of which were shared between sites. Haplotype and nucleotide diversity were moderately (Laguna Santa Tecla) to extremely (Teclitas) low, though significant genetic structure was observed between these remnant populations. Combined with the small size and number of remaining populations and the increasing exploitation of water resources for agriculture in the region, findings from this study provide additional evidence to support growing concern over the conservation status of this endangered, microendemic species. While the degree to which contemporary genetic diversity and population structure reflect historical versus anthropogenic effects is unknown, this distinction is critical to consider.

Although recent human activities have reduced habitat and population size of $X$. gordoni, at least 3 factors suggest that low mtDNA diversity is a historical condition. First, the Cuatro Ciénegas platyfish has been confined to a microgeographic distribution, and probably a narrow habitat breadth, for a considerable portion of its history (Minckley 1969). Second, low sequence diversity among extant haplotypes is consistent with a longterm influence of high rates of genetic drift (i.e., small effective population size, $N_{e}$ ). Finally, comparable population genetic diversity and structure have been documented in the endemic pupfishes Cyprinodon atrorus and Cyprinodon bifasciatus (Carson and Dowling 2006), species characterized by high population fragmentation of demonstrably ancient origin. Historical constraints on and recent anthropogenic losses in genetic diversity of $X$. 
gordoni, however, are not mutually exclusive, as recent habitat and population declines could have exacerbated long-existing downward pressures on genetic variability. Similarly, significant population structure in $X$. gordoni, while likely to be a consequence of high genetic drift within recently isolated subpopulations, may have existed previously but became more pronounced following anthropogenic perturbation.

While $X$. gordoni was likely characterized by relatively low genetic diversity prior to human influence, recent habitat loss and consequent population decline raise concern that this species is at appreciable risk of extinction from demographic and genetic factors, especially given increasing local demands on water resources. From an adaptive standpoint, this concern is well grounded. Specifically, Kallman (1964) performed an intrasib tissue-graft experiment on Monterrey and northern (= Cuatro Ciénegas) platyfish wherein a low but notable percentage of tissue grafts to $X$. couchianus gordoni $(=X$. gordoni) were accepted (survived), and many failed grafts exhibited chronic rejection over weeks or months. These results indicated that donor-host differences among histocompatibility genes were few to none, which led Kallman to argue that increased homozygosity at these loci was a consequence of genetic drift in this small population. Collections of Kallman (1964) were made in 1961, thus it is uncertain whether low variation at histocompatibility loci was historical or arose after population decline associated with initial construction of Canal de la Polilla ca. 1890-1910 (Minckley 1969); it is also unknown whether greater similarity among these loci has accrued since the alteration of Canal de la Polilla in 1964 brought further habitat reduction (Minckley 1969, Minckley personal communication).

Even if $X$. gordoni was able to accommodate relatively low genetic diversity in the past, recent population declines, high intrasib similarity at histocompatibility loci, and low mtDNA sequence variation raise concern over the continued ability of this species to absorb the negative effects that attend a small effective population size. Effective population size is predictive of extinction risk from genetic factors such as fixation of deleterious alleles, loss of adaptive genetic variation, and responsecapacity to natural selection and environmental perturbation (Franklin 1980, Lynch et al. 1995). Specifically, reduced genetic variation and increased inbreeding can constrain the ability of a population or species to adapt to environmental change (Frankham 1995), and the level of genetic variation within populations and species is known to correlate with population fitness (Hedrick and Kalinowski 2000, Reed and Frankham 2003).

The microendemic Cuatro Ciénegas platyfish is among a suite of native and endemic organisms at risk of extirpation or extinction as a consequence of water-resource exploitation in the region. While efforts to conserve $X$. gordoni will benefit from the population genetic baseline this study established for mtDNA sequence variation at cyt $b$, additional surveys that incorporate multilocus nuclear DNA markers, such as microsatellites, are needed to provide more robust assessments of genome-wide genetic variance, as well as reliable estimates of effective population size. Addition of such loci will also help determine the relative influences of historical versus recent effects on genetic diversity. Also, along with better characterization of the basic biology of this species, conservation efforts should include development of a long-term population and genetic monitoring program that is tied to (1) establishment of captive or refuge populations, the latter of which could be placed in suitable but vacant habitats within the historic range of this species and (2) additional habitat restoration and improvement. This integrated approach to conservation management of the Cuatro Ciénegas platyfish will facilitate early detection of population genetic change (negative or positive), reduce demographic and genetic risk of extinction, and potentially allow population expansion of this critically endangered, microendemic species.

\section{ACKNOWLEDGMENTS}

We thank Hailey Conover and Michelle Sandoval for invaluable assistance in the laboratory and Alexandra Snyder for curatorial expertise. Genetic data acquisition and analyses were performed in the laboratory of Thomas $\mathrm{F}$. Turner. The Carlos Slim Foundation and WWF México provided funding. All specimens were collected in accordance with Pesca de Fomento permit no. DGOPA00889.280211-0349 to Hector Espinosa-Pérez. 


\section{Literature Cited}

Carson, E.W., and T.E. Dowling. 2006. Influence of hydrogeographic history and hybridization on the distribution of genetic variation in the pupfishes Cyprinodon atrorus and C. bifasciatus. Molecular Ecology 15:667-679.

Culumber, Z.W., D.B. Shepard, S.W. Coleman, G.G. Rosenthal, and M. Tobler. 2012. Physiological adaptation along environmental gradients and replicated hybrid zone structure in swordtails (Teleostei: Xiphophorus). Journal of Evolutionary Biology 25: 1800-1814.

Cummings, M., and D. Mollaghan. 2006. Repeatability and consistency of female preference behaviours in a northern swordtail, Xiphophorus nigrensis. Animal Behaviour 72:217-224.

Elser, J.J., J.H. Schampel, F. Garcia-Pichel, B.D. Wade, V. Souza, L. Eguiarte, A. Escalante, and J.D. FARMER. 2005a. Effects of phosphorus enrichment and grazing snails on modern stromatolitic microbial communities. Freshwater Biology 50: $1808-1825$.

Elser, J.J., J.H. Schampel, M. Kyle, J. Watts, E.W. CarSon, T.E. Dowling, C. Tang, and P. Roopnarine. 2005b. Response of grazing snails to phosphorus enrichment of modern stromatolitic microbial communities. Freshwater Biology 50:1826-1835.

ExcoffiER, L., AND H.E.L. LISCHER. 2010. Arlequin suite ver 3.5: a new series of programs to perform population genetics analyses under Linux and Windows. Molecular Ecology Resources 10:564-567.

Frankham, R. 1995. Conservation genetics. Annual Review of Genetics 29:305-327.

FrankLin, I.R. 1980. Evolutionary change in small populations. Pages 135-148 in M.E. Soule, B.A. Wilcox, editors, Conservation biology: an evolutionary-ecological perspective. Sinauer Associates, Sunderland, MA.

FU, Y.-X. 1997. Statistical tests of neutrality of mutations against population growth, hitchhiking, and background selection. Genetics 147:915-925.

FU, Y.-X., AND W.-H. LI. 1993. Statistical tests of neutral mutations. Genetics 133:693-709.

Goudet, J., M. Raymond, T. De Meeüs, and F. Rousset. 1996. Testing differentiation in diploid populations. Genetics 144:1933-1940.

Hedrick, P.W., and S.T. Kalinowski. 2000. Inbreeding depression in conservation biology. Annual Review of Ecology and Systematics 31:139-162.

Hershler, R. 1984. The hydrobiid snails (Gastropoda: Rissoacea) of the Cuatro Ciénegas basin: systematic relationships and ecology of a unique fauna. Journal of the Arizona-Nevada Academy of Science 19: $61-76$.

Jones, J.C., J.-A. Perez-Sato, And A. Meyer. 2012. A phylogenetic investigation of the hybrid origin of a species of swordtail fish from Mexico. Molecular Ecology 21:2692-2712.

Kallman, K.D. 1964. Genetics of tissue transplantation in isolated platyfish populations. Copeia 1964:513-522.

Lynch, M., J. Conery, AND R. Burger. 1995. Mutational meltdowns in sexual populations. Evolution 49 1067-1080.

LYSNE, J.H. 1967. Histocompatability studies of the northern platyfish, Xiphophorus gordoni (Poeciliidae). Doctoral dissertation, Arizona State University, Tempe, AZ.
Meyer, A., J.M. Morrissey, and M. Schartl. 1994. Recurrent origin of a sexually selected trait in $X i$ phophorus fishes inferred from a molecular phylogeny. Nature 368:539-542.

Meyer, A., W. Salzburger, and M. Schartl. 2006. Hybrid origin of a swordtail species (Teleostei: $X i$ phophorus clemenciae) driven by sexual selection. Molecular Ecology 15:721-730.

Miller, R.R., AND W.L. Minckley. 1963. Xiphophorus gordoni, a new species of platyfish from Coahuila, México. Copeia 1963:538-546.

MinckLey, W.L. 1969. Environments of the Bolsón of Cuatro Ciénegas, Coahuila, México, with special reference to the aquatic biota. Texas Western Press, University of Texas El Paso Science Series 2:1-65. 1984. Cuatro Cienegas fishes: research review and a local test of diversity versus habitat size. Journal of the Arizona-Nevada Academy of Science 19: 13-21.

Orr, H.A., J.P. Masley, and D.C. Presgraves. 2004. Speciation genes. Current Opinion in Genetics and Development 14:675-679.

Patton, E.E., D.L. Mitchell, and R.S. Nairn. 2010. Genetic and environmental models in fish. Pigment Cell and Melanoma Research 23:314-337.

Raymond, M., and F. Rousset. 1995. An exact test for population differentiation. Evolution 49:1280-1283.

Reed, D.H., and R. Frankham. 2003. Correlation between fitness and genetic diversity. Conservation Biology 17:230-237.

Rosen, D.E. 1979. Fishes from the uplands and intermontane basins of Guatemala: revisionary studies and a comparative geography. Bulletin of the American Museum of Natural History 162:269-375.

Rosen, D.E., And R.M. Bailey. 1963. The poeciliid fishes (Cyprinodontiformes): their structure, zoogeography, and systematics. Bulletin of the American Museum of Natural History 126:1-176.

Rosen, D.E., and K.D. Kallman. 1969. A new fish of the genus Xiphophorus from Guatemala, with remarks on the taxonomy of endemic forms. American Museum Novitates 2379:1-29.

Rozas, J., J.C. SÁnchez-Del Barrio, X. Messeguer, and R. ROZAS. 2003. DNASP: DNA polymorphism analyses by the coalescent and other methods. Bioinformatics 19:2496-2497.

SCHARTL, M. 1995. Platyfish and swordtails: a genetic system for the analysis of molecular mechanisms of tumor formation. Trends in Genetics 11:185-189.

Schmidt, T.R., J.P. BiELAwsKI, AND J.R. GOLD. 1998. Molecular phylogenetics and evolution of the cytochrome $b$ gene in the cyprinid genus Lythrurus (Actinopterygii: Cypriniformes). Copeia 1998:14-22.

Souza, V., L. Espinosa-Asuar, A.E. Escalante, L.E. Eguiarte, J. Farmer, L. Forney, L. Lloret, J.M. Rodríguez-Martínez, X. Soberón, R. Dirzon, and J.J. ELSER. 2006. An endangered oasis of aquatic microbial biodiversity in the Chihuahuan Desert. Proceedings of the National Academy of Sciences, USA 103:6565-6570.

Souza, V., J.L. Siefert, A.E. Escalante, J.J. Elser, And L.E. Eguiarte. 2012. The Cuatro Ciénegas basin in Coahuila, Mexico: an astrobiological Precambrian park. Astrobiology 12:641-647.

Tamura, K., D. Peterson, N. Peterson, G. Stecher, M. NEI, AND S. Kumar. 2011. MEGA5: molecular evolutionary genetics analysis using maximum likelihood, 
evolutionary distance, and maximum parsimony methods. Molecular Biology and Evolution 28: 2731-2739.

Tibbets, C.A., And T.E. Dowling. 1996. Effects of intrinsic and extrinsic factors on population fragmentation in three species of North American minnows (Teleostei: Cyprinidae). Evolution 50:1280-1292.

VOLFF, J.N. 2005. Genome evolution and biodiversity in fish. Heredity 94:280-294.
Winsborough, B.M. 1990. Some ecological aspects of modern fresh-water stromatolites in lakes and streams of the Cuatro Cienegas basin, Coahuila, Mexico. Doctoral dissertation, University of Texas, Austin, TX.

Received 19 October 2012 Accepted 13 February 2013 